\title{
EL DRAE (1817-1852) A TRAVÉS DE LA PRENSA ESPAÑOLA
}

\section{THE DRAE (1817-1852) THROUGH THE SPANISH PRESS}

\author{
Miguel Ángel Puche Lorenzo \\ Universidad de Murcia y grupo Neolcyt (UAB) \\ mapuche@um.es
}

Recibido: 19/10/2018

Aceptado: 08/01/2019

\begin{abstract}
Resumen
Durante el siglo XIX, la actividad periodística se multiplica con respecto a épocas anteriores. La prensa se erige en un testimonio indispensable para conocer la evolución de la lengua. Además, quienes escriben en esas publicaciones muestran sus opiniones respecto a los usos y las obras de carácter lingüístico. La divulgación de esas opiniones podría incidir en los lectores, influyendo en el criterio que adoptarían ante aquellos. Por ello, se estudia la presencia del diccionario académico, correspondiente a las ediciones comprendidas entre 1817 y 1852 , en las páginas de la prensa para analizar las opiniones que de él se vertían o las correcciones que se sugerían. A través de ellas, conoceremos con mayor exactitud la extensión social del diccionario, la evolución que se produjo en las sucesivas ediciones o la influencia que ejerció el periodismo para modificar determinadas definiciones o incluir nuevos lemas.

PALABRAS CLAVE: Periodismo, Lexicografía académica, Historia de la Lexicografía, Historia del Léxico, DRAE
\end{abstract}

\begin{abstract}
During the 19th century, the journalistic activity is multiplied with respect to former times. The press stands in testimony essential to uderstand the evolution of the language. In addition, people who write in these publications show their opinions regarding applications and linguistic Works. The disclosure of these views could influence the readers, inluencibg the criterion that would take before those. For this reason, the presence of the academic dictionary, corresponding to the editiosn between $1817-1852$, is studied in the pages of the press to discuss opinions that are poured or corrections that are suggested. Through them, we will know more accurately the social extensión of the dictionary, the evolution that occurred in successive editions or influence that practiced journalism to change certain definitions or include new slogans.
\end{abstract}

KEY WORDS: Journalism, acedemic lexicography, history of lexicography, history of the lexicon, DRAE

Para citar este artículo / To cite this article: Puche Lorenzo, Miguel Ángel (2019). El DRAE (1817$1852)$ a través de la prensa española. Azorín, Dolores; Clavería, Gloria y Jiménez Ríos, Enrique (Eds.): ELUA: El diccionario de la Academia y su tiempo: lexicografí, lengua y sociedad en la primera mitad del siglo XIX, Anexo V, págs. 65-88.

Enlace/Link: http://dx.doi.org/10.14198/ELUA2019.ANEXO5.04 


\section{INTRODUCCIÓN}

La prensa ha sido, y es, desde su nacimiento un fiel reflejo de la sociedad en la que emerge. En España, esta actividad encuentra su origen en el siglo XVII con la Gazeta de Madrid. Aunque estaba destinada, en un primer momento, a una minoría culta, en el siglo XIX se dio paso a un periodismo liberal, acorde con la situación política, que se inicia en 1808 con la primera libertad de imprenta, a pesar de que no fuera efectiva o similar a la que conocemos en la actualidad. Se constatan, por tanto, desde los inicios de este siglo, las tendencias liberales y afrancesadas que subyacen en los periódicos del momento. No obstante, el interés que se descubre en estos años consiste en que el periodismo deja de ser ese medio para la minoría culta del siglo anterior, en virtud de que adquiere "la condición de instrumento de movilización social y política al servicio de la causa liberal" (Barrera 2000: 19), a la vez que surgen otros modelos de prensa sin ese marcado tinte político, como sucedió con El Siglo Pintoresco, basado en la ilustración gráfica. Así mismo, se fue desarrollando la conocida como prensa informativa, aceptada con mayor estima por los lectores puesto que se dedicaba a "contar noticias", modelo que iría evolucionando hasta el sensacionalismo informativo que se fraguó con mayor consistencia a partir del crimen de la calle Fuencarral, ya en 1888. El interés social que había adquirido el periodismo durante este siglo fue objeto, incluso, de discursos de recepción en la Real Academia, como los de Joaquín Francisco Pacheco en 1845 y Eugenio Sellés en 1895, hecho este que pone de manifiesto el relieve adquirido por el periodismo dentro del mundo académico, de la lengua y la literatura ${ }^{1}$ (Barrera 2000: 20 y ss.).

Si nos remitimos al discurso de Sellés, encontraremos una clara explicación del modo en que había evolucionado la prensa durante el siglo XIX y la estrecha relación mantenida con la lengua y, en particular, con las palabras. En sus páginas, se traza el devenir que había sufrido y establece una defensa para alzarlo como otro género literario más, haciéndose eco de las aportaciones de quienes le precedieron, como Pacheco ${ }^{2}$. A esas alturas, se había constituido como una fuerza social que, debido al carácter voluntario de su lectura, ocasionaba el denominado poder de la sugestión, es decir, el de autoridad sobre la sociedad, independientemente del mayor o menor nivel cultural que dispusiera. A pesar de que, en cuestiones de la lengua, "es rebelde a la gramática, contrabandista de locuciones y palabras extranjeras, corredora de frases hechas, tomadas de ese idioma peculiar, ó mejor dicho dialecto de la política y de la mala oratoria parlamentaria", el paso del tiempo dio lugar a que se escribiera, en el siglo XIX, mejor que se escribía puesto que "Está abolido el lenguaje ó pedestre ó ampuloso herencia del mal gusto del siglo pasado... Háblase con llaneza adecuada á la realidad y al entender común, y aún se advierte cierto amor, no siempre bien espresado, á lo castizo". Se puede decir, en sus palabras, que el periódico se convirtió en el "libro del pobre"; en consecuencia, ha permitido enseñar a leer a gente que no sabía y su lectura influye en el cambio de la sociedad de ahí que, las clases trabajadoras, singularmente

1 A principios del siglo XX, este "género" volvió a ser objeto de otro discurso académico, en este caso el de José Francos Rodríguez en 1924 y, con posterioridad, en 1984, Francisco Ayala se ocupó de la retórica del periodismo (Álvarez de Miranda 2011: 24 y 65-106)

2 La referencia del discurso pronunciado en 1845 ha sido extraída del texto de Sellés (1895). Los discursos se establecieron como "norma" a partir de 1848 y, ya en el siglo XX, al periodismo se refirió también el pronunciado por Francos Rodríguez en 1924 (Álvarez de Miranda 2011). 
las de las ciudades más pobladas hablaran con el lenguaje y los modismos del periódico y con razones que él les prestaba (Sellés 1895: 33-35)․․ Afirmaciones estas que nos serán de gran utilidad para comprender el tema que aquí se desarrollará; a ellas se suma el hecho de que será el medio más oportuno para convertirse en foro donde exponer ideas, teorías o entablar discusiones públicas sobre cuestiones de actualidad.

Con estas palabras iniciales, queda justificado el valor social y la influencia que podría ejercer entre los lectores la prensa decimonónica. Por ello, el objetivo marcado consistirá, principalmente, en observar y comprobar cómo percibió este medio de comunicación la labor lexicográfica de la Real Academia y, en consecuencia, si aportaciones que aparecieron publicadas en las páginas de los diferentes periódicos pudieron influir en su devenir. El marco temporal acotado no se corresponde con la totalidad del siglo XIX, puesto que nos ceñiremos a la primera mitad de la centuria, concretamente a aquellas colaboraciones que tengan por objeto las ediciones del diccionario comprendidas entre 1817 y 1852 . El corpus sobre el que hemos elaborado este trabajo está conformado por la prensa de la época. Consulta que se ha realizado a través de los ejemplares digitalizados y fácilmente accesibles en la Hemeroteca digital de la Biblioteca Nacional ${ }^{4}$. Se ha pretendido llevar a cabo una visión lo más exhaustiva y minuciosa posible, por lo que se ha procurado el vaciado y la lectura de todos los ejemplares publicados, y en esa página web contenidos, entre 1817 y 1868 con el fin de tener completo el lapso temporal que mantuvo "vigentes" las ediciones del diccionario académico antes referidas.

En virtud de que el material extraído es extremadamente rico y de gran valor, resultará imposible dejar constancia de todo él aquí. No obstante, sí quedarán visibles las principales líneas que se advierten en las diferentes colaboraciones publicadas y que nos ampliarán la visión y la concepción del diccionario, o diccionarios, en el contexto de la época que los vio nacer. El método de trabajo que se ha adoptado intentará contrastar y conjugar la visión externa e interna de esta obra lexicográfica, mediante los argumentos más variados, hallados e interpuestos, a veces, por individuos alejados no solo del quehacer lexicográfico en particular, sino también del lingüístico, en general.

\section{EL DICCIONARIO EN EL SENO DE LA SOCIEDAD DECIMONÓNICA}

Dado que el objetivo marcado en este trabajo no es ningún estudio lingüístico del periodismo, sino del periodismo sobre la lengua, del diccionario concretamente, las noticias,

3 Durante la primera mitad del siglo XIX, se mencionan estos condicionantes en la prensa. Alberto Lista, en la Gazeta de Sevilla (13 de febrero de 1810) indica que "Es harto conocida la influencia de los buenos periódicos en la instrucción de las naciones. Son los vehículos por donde pasan los conocimientos útiles de la clase instruída que por su profesión cultiva las letras, al resto de los ciudadanos, que, distraídos por otras obligaciones del manejo de los libros y de la carrera del saber, son, no obstante, los que deben gozar el fruto de las tareas de los literatos" (ápud Barrera 2000: 65). En el caso concreto de la lengua, Navarro Villoslada declara su política editorial al respecto al afirmar que "Nuestro lenguaje, sin embargo, aun cuando ventilemos grandes y profusas cuestiones, será sencillo y acomodado á la inteligencia de todos los talentos medianamente cultivados. Mal podríamos de otro modo conseguir nuestro objeto de estender y popularizar la lectura de escritos sérios y amenos, introduciendo este periódico en el seno de las familias, para fortificarlas en sus creencias y disminuir sus ratos de ócio y de fastidio" (El Siglo Pintoresco, abril de 1845: 3)

4 Se ha accedido también a otros recursos virtuales como el portal de la Prensa Virtual Histórica (http:// prensahistorica.mcu.es), entre otros, puesto que algunos ejemplares consultados se encontraban en mal estado y resultaban ilegibles. 
en su más diversa forma, serán el sustento del análisis que proponemos desarrollar ${ }^{5}$. Antes de comenzar con el estudio de la repercusión y las implicaciones sociales que tuvieron las ediciones del diccionario académico aparecidas entre 1817 y 1852, se ha creído conveniente indicar, de forma previa, qué importancia había adquirido el diccionario dentro de la sociedad decimonónica. Se convertirá este breve acercamiento en una introducción que nos permitirá comprender por qué el diccionario podía ser noticia y formar parte de alguna columna informativa del más variopinto contenido.

Sin necesidad de retroceder, en esta ocasión, al origen y al pasado de nuestra tradición lexicográfica, con nombres como Nebrija o Covarrubias, hemos de indicar que la publicación del denominado Diccionario de Autoridades, una vez fundada la Real Academia, y bajo la luz del espíritu ilustrado, tuvo como consecuencia la difusión del diccionario entre las capas sociales más cultas. Aunque, en virtud de las ediciones posteriores, reducidas y más asequibles, esa difusión fue acrecentándose hasta convertir a este tipo de obras en obligadas y obligatorias dentro de la educación y la formación cultural de los hablantes. Al ser este un hecho que iba adquiriendo mayores proporciones con el paso de los años, no extraña comprobar cómo, en el inventario de los objetos que debe tener una clase, figura un diccionario:

Un cartón ó caja de estampas. Un diccionario de la lengua castellana ${ }^{6}$. Un número de pizarras y de lápices proporcionado al de los discipulos. Una mesa para escribir en pié. Tres rejistros y un cuaderno de notas, de cuyo uso hemos hablado ya. Un silvo y una campanilla. Un llamador de madera en forma de libro. Una ó mas filas de perchas para colgar las górras y ropas durante las horas de clase ó de recreo. Doce esponjas pequeñas y dos grandes [...] (El panorama, 1/6/41: 4)

Unida a la formación docente, se sitúa la gran utilidad que proporciona el diccionario para conseguir hablar con propiedad y utilizar las palabras con el significado preciso. El uso adecuado de la lengua es, por consiguiente, el fiel reflejo de la formación adquirida:

Cuando se pasa mucho tiempo sin leer, se pierde el interés de la lectura, y por esto es muy ventajoso tener a mano obras escojidas, á las que se puedan pedir, siempre que se quiera, distracciones y consejos. Una de las mas indispensables, á mí modo de ver, por su mucha utilidad, es un buen Diccionario de la lengua castellana, porque nada da mejor idea de nuestra instrucción, que el saber emplear para espresarnos los términos mas adecuados. Así, pues, te aconsejo que cuando una palabra no tenga para tu comprensión un significado claro, recurras sin pérdida de tiempo al Diccionario, para no emplearla jamás á la ventura. (La Educanda, 16/6/63: 2)

Las tropelías cometidas en el uso de las palabras podían parecer escandalosas en determinados sectores, como el político, que se consideran, en el ámbito periodístico, como un grave insulto hacia el diccionario, a pesar de que, la mayoría de las veces, se trate de errores gramaticales. Así se llegó a expresar:

5 Los periódicos que se citarán en el transcurso de este estudio han sido consultados a través de la Hemeroteca digital de la Biblioteca Nacional de España (http://www.bne.es/es/Catalogos/HemerotecaDigital/). Al final se indicará el listado de los títulos utilizados en el desarrollo de nuestra investigación.

6 Los subrayados que aparezcan en las citas utilizadas son nuestros. 
En Las Cortes se lee lo que sigue: “Aunque con muchísima reserva, la cual nosotros encargamos también igualmente á nuestros suscritores, se nos ha asegurado que á consecuencia de los graves insultos que el Diccionario de la lengua castellana recibe todos los días en cierta numerosa reunión hasta de personas muy respetables y formales que á ella asisten, ha resuelto al fin pedir sus pasaportes. Aparte del que dice pluga y cuala, Prógrama, dedució y otras lindezas, Tales los hay en lo de hablar, que á voces Los está reclamando la Academia. Muy serio esclama aquel: prenunciamiento. Muy grave el otro al par: indiferiencia. De péritos y méndigos, ;oh, escándalo! Abundante por cierto es la cosecha, Y según se los ve, no será estraño. Si Dios por compasión no lo remedia. Que prenunciando salga alguno de ellos. Pues de que ocurra así las trazas llevan, El estógamo, enantes, la vinagre, Alifonso, el murciégalo, la audencia, Percurador, precurador, cocote, Anecdota, treato y la concencia. (La Esperanza, 16/2/ 55: 4)

No resulta extraño, por tanto, que el consejo dirigido a quienes ocupen esa profesión sea la consulta del diccionario, entre otras posibilidades, con el fin de mejorar su imagen y que esta adquiera el verdadero valor de la instrucción recibida:

No es, en efecto, necesario para ser diputado poseer las dotes de Cicerón; pero el que carezca de ellas no está dispensado por eso de conocer, al menos, la gramática, y haber consultado alguna vez el Diccionario de la lengua castellana. (La Iberia, 13/12/54: 1)

Consejo este que se hace extensivo a otros dominios, como sucede con la medicina. Como muchas de las obras de esta materia eran traducciones, se aconseja al que a estos menesteres se ocupa que, antes de cometer disparates, disponga de un diccionario a su lado:

[...] Como mi piadosa obligación es la de poner remedio á los males que lo tuviesen, no me es posible dejar abandonados, á su suerte á estos pobrecitos sin recetarles el que su estado reclama: asi, quiero y mando, que al escribiente olvidadizo se le obligue durante un año á leer pausadamente y por tres horas diarias, en un libro que se llama Gramática de Salva: que al exactísimo cajista se le ponga á su lado en el sitio donde componga, un atril con el Diccionario de la lengua castellana aunque sea de la ediccion mas barata é incompleta, para que pueda hallar la palabra que no entienda [...] (Boletín de medicina, cirugia y farmacia, 10/7/40: 4)

A través de testimonios como los presentados, la lectura del título parece sugerirnos que el diccionario recomendado hasta ahora es el académico, aunque no exista especificación alguna en cuanto a la autoría. Pero a partir de este último ejemplo, se deja patente la idea de otras obras lexicográficas que también podrían adquirir esa utilidad. Conforme vaya avanzando el siglo y existan otros diccionarios en el mercado, así podría entenderse y así se indica en la contestación realizada desde la redacción de un periódico, El moro Muza, ante los desatinos que se producen en el uso del léxico:

Si V. no lo toma por agravio, la Redaccion de "El Moro Muza" animada de los sentimientos mas humanitarios y siguiendo la saludable máxima de enseñar al que no sabe, está pronta á obsequiar á V. con un ejemplar del Diccionario de la Academia ó del Panléxico, ó del de Chao, ó del de Domínguez, ó del de Caballero, á fin de que V. lo consulte antes de espetar fallos, ó mejor dicho, tiros que le salen por la culata. (El moro Muza, 20/11/59: 3)

7 Es esta una ácida crítica vertida a un joven escritor que publicaba en un periódico de La Habana. 
El Diccionario, y esta vez sin lugar a dudas se trata de la obra académica, había sido objeto de atención desde las más diversas perspectivas y para los más variados usos. A su estructura y al universo interno que encierra dedicó Galdós una de sus primeras obras, publicada en el periódico La Nación, bajo el título La conjuración de las palabras. El Diccionario, en su décima edición, se constituye en el protagonista del extraño relato, a la vez que funciona como alegoría de la situación política española en aquel momento (Morales Umpiérrez, 2013: 142) ${ }^{8}$ :

Erase un gran edificio llamado Diccionario de la lengua castellana, cuyo tamaño era tan colosal y fuera de medida, que, al decir de los cronistas, ocupaba casi la cuarta parte de una mesa, de estas que, destinadas á muchos usos, vemos en las casas de los hombres. Si hemos de creer á un viejo documento hallado en un viejísimo pupitre, cuando ponían al tal edificio en el estante de su dueño, la tabla que le sostenía amenazaba ruina, con detrimento de todo lo que encima habia. Formábanlo dos anchos murallones de cartón, forrados en piel de becerro jaspeado, y en la fachada, que era también de cuero, se veia un ancho cartel con letras doradas, que decían al mundo y á la posteridad el nombre y la significación de aquel gran monumento. Por dentro era una maravilla tan curiosa, que ni el mismo laberinto de Creta se le igualara. Divídíanlo hasta seiscientos tabiques de papel con sus números llamados páginas; cada tabique estaba subdividido en tres galerías ó columnas muy grandes, y en estas galerías se hallaban innumerables celdas, donde vivían los ochocientos ó novecientos mil seres que en aquel vastísimo y complicado recinto tenian su habitacion. Estos seres se llamaban palabras. (Benito Pérez Galdós, La Nación, 12/2/1868: 3)

La intervención social del diccionario no queda ahí. En estos momentos de nuestra historia, se produjo una trama conspiratoria contra el gobierno de Isabel II. La suplantación de identidad, la falsificación documental, las calumnias, entre otros motivos, llevaron a considerar esta trama como de alta traición. El proceso se hizo con prontitud un innegable hueco en las páginas de la prensa coetánea, donde se describían los hechos de forma pormenorizada y se daba cabida a que los encausados pudieran dar su versión de los acontecimientos. El desenlace acabó inculpando a todos los participantes, principalmente a los "falsos" barones de Boulow y Pelichy y a Manuel de Toro y Pareja, conocido por ser redactor de una historia de la milicia nacional ${ }^{9}$. La conjuración se detuvo porque se interceptaron cartas redactadas con cifras y letras convencionales. Resulta interesante traer a colación este asunto, porque el medio utilizado para redactar y pasar de unos a otros la correspondencia era francamente original. Se procedió a hacerlo mediante el Diccionario académico, concretamente la novena edición (1837), es decir, esta obra se convirtió en la protagonista de una interesante conjuración política de la España del momento.

y se introdujeron furtivamente en la habitación del que revistieron con el carácter de jefe de la conspiración para hacer la aprehension en el acto de un segundo reconocimiento preparado al intento, haciéndole también recibir, con la arteria mas villana, el diccionario de la lengua castellana de la novena edición, que habían elejido como clave para la traducción de la mencionada correspondencia enigmática: maldades todas, tan hábil y diestramente

8 El texto fue reeditado posteriormente en la novela Torquemada y ha sido objeto de diversos estudios, entre los que destacamos los de Peñate Rivero (1989) o Shoemaker (1972).

9 El título completo es Historia de la milicia nacional desde su creación hasta el desarme general. Sociedad tipográfica de Don Benito Hortelano y Compañía. Madrid, 1845. 
combinadas para presentar la trama con los caracteres de la verdad legal [...] Añade Pélichy al folio 455 que también supo por Gimeno que, entre Carrasco y demas cómplices se había resuelto introducir en casa de Toro el diccionario de la lengua castellana de la novena edición, propio de Carrasco, y del cual se había valido este para la formación de las facturas enigmáticas, á fin de que encontrándolo en poder de Toro pudiese servir de comprobante para la supuesta conspiración (El clamor público, 19/9/1845: 3 y ss.)

Si con estos datos resulta factible comprobar el valor social que había adquirido el diccionario, aunque de momento solo nos referimos a su forma, también es objeto de atención la ampliación semántica que había adquirido esa voz, motivada esta por un trasunto metafórico o metonímico. De hecho, en estos momentos "diccionario" no es solo ese repertorio donde se recogen, por orden alfabético, las palabras de una lengua, sino que también se utiliza para referirse al léxico disponible de un hablante concreto ${ }^{10}$, un sector de la sociedad o de un medio. En otros tipos textuales ya se había producido una identificación entre lengua y diccionario, como ha advertido Garriga Escribano (2018: 315) en las traducciones efectuadas por los químicos españoles.

Conocemos la nomenclatura de la prensa apasionada é intolerante, en que ninguna diferencia se hace entre la franca oposición y la violenta animosidad entre la cortesía y la bajeza. En su diccionario todo elogio es adulación, toda critica es sátira, todo argumento personalidad. (El corresponsal, 29/5/1840, p. 1)

Reciente y antigua; implicat in terminis. No obstante en lo demás razón tiene el articulista, porque en su diccionario, abuso vale un hecho según las leyes vigentes y asi la comunidad cometió abusos por el mismo hecho de haberse arreglado á las leyes que entonces reglan. (Diario constitucional de Palma, 9/3/1840, p.4)

En el siguiente número, un articulo entero de redacción sirvió de desahogo al furor de nuestro colega, que apuró su diccionario de anarquía, de desorden, de trastorno y de cuantos términos usa cuándo se trata de denigrar á un partido (Eco del comercio, 12/12/1839: 4)

\section{EL DICCIONARIO COMO AUTORIDAD LÉXICA}

Tras la exposición del marco externo que demuestra el relieve adquirido por el diccionario académico, se acrecienta el interés por cuestiones que, en las páginas de la prensa del periodo acotado, emergen desde los ámbitos más diversos y que nos permitirán aproximarnos o acceder a una visión enriquecedora de la magna obra académica. En consecuencia, resulta imprescindible evaluar, como punto de partida, el papel desempeñado por el diccionario como una verdadera autoridad en el plano léxico de nuestra lengua. Se recurre a él con el fin de demostrar la validez o no de una palabra, es decir, si el significado aportado o con el que es utilizada es apropiado. Para ello, puede reflejarse solamente el título de la obra:

Prosigue, si en todas las cláusulas del §. 2. no se advirtiera un empeño obstinado en sostener su chichisveo. Válgame Dios; el chichisveo me aplica ahora el impugnador, como si le contase mi voluntad, genio y bolsillo estuviesen conformes para hacer un obsequio

10 Esta acepción no ha sido recogida por ningún diccionario. Solamente Rodríguez Navas parece aproximarse al significado que adquiere en los ejemplos que mostramos. La consulta de los diccionarios, anteriores a 1992, citados en el desarrollo de este trabajo se ha realizado a través del Nuevo Tesoro Lexicográfico de la Lengua Española en línea (www.rae.es). 
continuado á una muger, que es el sentido que da á la voz chichisveo el Diccionario de la lengua castellana. (Crónica científico y literaria, 4/2/1820: 2) $)^{11}$

Aquí llegaba con mi raciocinio, cuando me ocurrió acudir al diccionario de la lengua castellana, por si de él podría sacar algún fruto para conceder á V. la razón que no le hallaba; pero al darme en rostro la definición de "Soberano: el señor que tiene el dominio y manejo de sus vasallos absoluto y sin dependencia de otro superior", doblé la hoja diciendo, no, no es el Editor tan sandio que la usase en este sentido, pues estando declarado el gobierno de la Nacion por el de Monarquía moderada, según el artículo $1^{\circ}$ y designado al REY el tratamiento de magestad católica por el 169, seria haberse propuesto el absurdo, aunque no desusado plan, de enseñar desenseñando. (Semanario político, 15/6/1820: 3 ) $^{12}$

leyó en el Diccionario de la lengua castellana la inteligencia de la palabra amnistía: olvido y perdón general que decreta un soberano en favor de algún pueblo ó persona. Criminum antea admissorum venia, et impunitas á principe oblata. Que si el Diccionario castellano tiene fuerza cuando se hacen leyes, es bien clara su inteligencia; mas si se atiende á la aserción latina del mismo Diccionario et impunitas, no deben exceptuarse los perjuicios de tercero. (Diario del Gobierno de los Estados-Unidos Mexicanos 18/2/35: 2) ${ }^{13}$

Otras veces se especifica que es obra de la Real Academia:

$\underline{\text { Con solo abrir el diccionario de la lengua castellana, compuesto por la Real Academia, }}$ se encontrará que la excelencia supone la perfeccion, grandeza y calidad que constituye y hace digna de singular aprecio y estimación alguna cosa, como excelencia de ánimo, de ingenio, de virtud, de doctrina, ó de otras cosas que son selectas y aventajadas en alguna clase y género. Asi lo primero que hay que hacer, antes de tributar á nadie el tratamiento de excelencia, es reflexionar á que parte de esta definición pertenece el sugeto (El censor 2174/1821: 24$)^{14}$

El Diccionario de la lengua castellana de nuestra real Academia, haciéndose cargo de la voz higa, la define diciendo: "Amuleto con que vanamente se persuadían los gentiles que se libraban del fascino y mal de ojo, y apartaba de sí los males que podian hacer los envidiosos, cuando miraban á las personas ó a las cosas. La figura era de una mano, cerrado el puño, mostrando el dedo pulgar por entre el dedo índice y el de en medio... (Museo de los niños $11 / 1849)^{15}$

\section{O, incluso, la edición manejada del diccionario:}

Señor Redactor del Correo: Tengo bastante educación y delicadeza para no contestar al artículo del Plagiario, inserto en el numero 285 de su apreciable periódico, en el mismo estilo que él usa conmigo. Era menester ser otro él para imitarle en este punto. La cuestión

11 La definición incluida está presente desde la edición de 1780, aunque desaparece a partir de 1869.

12 El artículo 169 se corresponde con el establecido en la Constitución de 1812, mientras que el primero está redactado de la siguiente manera: "Artículo 1: La Nación española es la reunión de todos los españoles de ambos hemisferios" ([2012]: 402). La definición estuvo presente en el diccionario académico desde Autoridades hasta la quinta edición de 1817. Para conocer mejor ese momento y las consecuencias en la institución académica vid. Battaner (2008).

13 Debió consultarse a partir de la sexta edición, 1822, dado que es el momento en que se introducen las mismas palabras.

14 El título del artículo es "Sobre la exactitud de la voz excelencia" y la definición copiada se corresponde con la aparecida en Autoridades.

15 El texto posee mayor extensión en justa correspondencia con la información que proporciona Autoridades. Se verá reducido y modificado a partir de 1791 . 
versa sobre un soneto inserto en el Correo del 7 de abril. Examínese este con imparcialidad, y se vera que el unico defecto que en suma se le ha puesto es la acepción metaforica o figurada en que pongo el verbo tocar. El que desee saber si está bien usado, que vea el diccionario de la lengua castellana por la Real Academia Española quinta edición, pág. 846, col $3^{\mathrm{a}}$, lín. 89 y siguientes, y se convencera de que la crítica es quimérica é infundada. Lorenzo de Alemany. (El correo, 12/5/1830: 3$)^{16}$

Los articulistas llegan a ser conscientes de que la divergencia en el significado radica en el hecho de pertenecer a dominios concretos:

En el diccionario de la lengua castellana no tiene esta palabra [proscripción] acepción que signifique el acto de violencia que hemos visto cometer en varios puntos de la península contra ciudadanos de todas clases. Es, dice, el bando con que se declara á alguno por público malhechor, con lo cual se entiende cierto acto propio de los tribunales de justicia, y asi es que el diccionario apellida forense á esta voz. A la terminología anárquica debemos recurrir para encontrar el justo significado de esta dicción espantosa. Proscribir, según se ha hecho en tumultos y levantamientos populares, es arrojar del seno de la sociedad á individuos, cuya seguridad personal las leyes protegían; es por consiguiente un acto desautorizado, depresivo de las leyes, violento y arbitrario. (El revisor semanal 8/6/1823: 8) (7) $^{17}$ Por lo demás, dejamos á la virtud cristiana de Pió IX el juzgar si debe agradecer que se le llame liberal, no en el sentido que da á esta palabra el diccionario de la lengua castellana, que es como nosotros con plena convicción se le daríamos, sino en el político que lo hace uno de nuestros mencionados colegas. (La Esperanza, 31/5/47: 1) ${ }^{18}$

\section{Aunque pueden llegar a coincidir:}

El Sr. secretario del despacho de GRACIA Y JUSTICIA: Yo rogaría á la comisión se sirviese borrar de este articulo una palabra, que es la siguiente. Dice: "haciendo compulsar los documentos." Compulsar, según el Diccionario de la lengua castellana, y segun también el significado forense, quiere decir copiar en forma legal, y no es esto sin duda lo que ha querido decir la comisión, porque como son documentos que están en el espediente, no hay necesidad de copiarlos (El español, 1/5/36: 2) ${ }^{19}$

\section{No se desentiende la prensa de crear definiciones en tono irónico o satírico:}

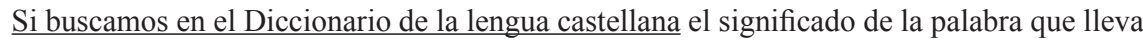
por título este articulo, encontraremos: $\underline{\text { Moda, }}$, el uso y estilo corriente y mas moderno en las cosas que dependen del gusto y del capricho; mas en mí pobre juicio no me parece esta la definición mas acertada. Yo hubiera dicho; moda, es un castigo universal impuesto por los hombres mismos, castigo oneroso á cuya tuerza todos doblan la cerviz y le siguen en

16 Contamos con el nombre del autor de este texto y, por la fecha, comprobamos que remite a la quinta edición cuando ya estaba en circulación la sexta. La acepción metafórica a la que se refiere estaba recopilada desde Autoridades.

17 A pesar de estar definida de esa manera desde Autoridades, en 1832 se añade "acción y efecto de proscribir", en 1869 se marca como anticuada, para después desaparecer esta definición y quedar hasta la actualidad.

18 La información tiene sentido porque no será hasta la décima edición, 1852, cuando la última acepción de esta palabra sea el neologismo emanado desde las corrientes políticas, aunque su uso como sustantivo no se registrará hasta 1884. La primera vez que se ha podido registrar esta voz fue en las Cortes de Cádiz (Moreno, 2009: 471-472). 19 En este caso no hay coincidencia con la definición académica en ninguna de las ediciones. Esto lleva a pensar que decidió incluir la proporcionada desde el ámbito forense. 
su incestante carrera, castigo del que ya sería imposible separarnos y que sin embargo nos pone en ridículo con bastante frecuencia. ¡A tal estremo nos conduce nuestra ceguedad! (La Ilustración, 1/3/51: 7)

También adquiere valor como autoridad ortográfica, es decir, no presta solo atención a aquellos asuntos relativos al significado de las palabras, sino también del significante:

En la calle de San Miguel se leo un rótulo que dice Despacho de yelo, y deseáramos saber de que pais del mundo es semejante producción. La palabra yelo no se encuentra en el Diccionario de la lengua castellana. ¡Cuántos disparates ortograficos como el presente se ven en las calles de esta corle, y cuan conveniente seria el nombramiento de una comisión que corrigiese estos absurdos! Pero por mas que la prensa ha repetido esta idea, el ayuntamiento no se da nunca por entendido. (El Heraldo 13/6/51: 3 )

Como norma general, no encontramos mencionada la edición correspondiente y, a través de las definiciones adjuntas, resulta difícil asegurar la que tuvieron en sus manos o consultaron estos escritores, salvo cuando se encuentra un claro antecedente en Autoridades. Este proceder parece indicarnos el prestigio del $D R A E$ durante esos años entre quienes no disponían de formación lingüística o gramatical. A ello se une un hecho que se presta a una doble interpretación: la venta de diccionarios anunciada en la prensa. Si tomamos como ejemplo el Diario de avisos de Madrid, del año 1838, cuando estaba en circulación la octava edición del diccionario, se ofrecen para vender ejemplares de la tercera, la cuarta o la séptima edición, junto a la última aparecida. El motivo podría deberse bien al prestigio de la obra, bien al hecho de no estar actualizadas y querer desprenderse de obras obsoletas. Así mismo, la observación de los ejemplos incluidos en este apartado nos permite constatar los importantes vaivenes a que fueron sometidos entre la quinta y la décima edición del diccionario.

\section{EL DRAE COMO OBJETO DE REVISIÓN SOCIAL}

La autoridad y, en consecuencia, el prestigio que desprende el acceso al diccionario para el uso correcto de la lengua no es general en la prensa de la primera mitad del siglo XIX. Quienes escriben en este medio y son cercanos al estudio de la lengua, o al menos preocupados por estos asuntos, ponen de manifiesto las discrepancias existentes entre el significado de determinadas palabras en el diccionario y en la sociedad, en parte porque los significados evolucionan al compás que lo hace aquella. Es en ese proceso cuando se advierten desajustes significativos, promovidos en las primeras décadas por cuestiones políticas y se tiende a denunciar o proclamar este hecho.

La tarea de los que se empeñan en conservar el lenguaje de sus abuelos va haciéndose cada dia mas difícil por falta de un diccionario comparado en que se note la significación antigua de las voces, y la acepción en que las usan los reformistas liberales. Porque error sería desconocerlo: nuestras poblaciones han sido invadidas por una casta de gente que, si no es en el vestir y en las costumbres, en lo cual se distinguen demasiado de los antiguos habitantes, en lo demás parecen españoles rancios como ellos. En cuanto al idioma principalmente, nadie dirá que no son de los nuestros; porque fuera de algunas voces de que se sirven enteramente estranjeras, las demas todas se hallan en el Diccionario de la lengua castellana. Pero no con la significación que ellos les dan, y aqui está el gran trabajo de los 
hablistas puros, proviniendo de aqui que mientras los liberales y los españoles por hablar una misma lengua, creen entenderse mutuamente, ninguno saca fruto de las exhortaciones que dirije al de distinta familia. (La Esperanza 9/7/51:1)

Este asunto lleva a constatar la presencia de neologismos, en su concepción social, pero también a partir de la sanción léxica que se inducía desde la lexicografía académica. Es el caso de dos neologismos que fueron estudiados por Álvarez de Miranda (1992: 261) de los que se dice:

Las palabras egoista y egoísmo deben ser ó muy modernas ó enteramente bastardas al idioma castellano, supuesto que ni una ni otra se encuentran en el Diccionario de la Real Academia española. Pero estan tan consagradas por el uso, que ya es tiempo de asignarlas una significación fija, determinando su sentido, de modo que la idea que representen, no pueda confundirse con ninguna otra. Diremos, pues, que el egoismo es el amor propio, que consiste en referir todas las cosas de su propia utilidad, ó en hablar mucho de si: y el egoísta es aquel ó aquella que sigue la doctrina del egoísmo. (El censor, 21/7/21: 27)

El texto apareció publicado en 1821 y el redactor que las incluía, probablemente Alberto Lista $^{20}$, no tuvo a mano la quinta edición. Sin embargo, introdujo en su propuesta de definición el concepto de "amor propio" que no se mencionaba en aquella, pero sí estará presente en la edición siguiente, la sexta (1822).

No obstante, las posibles mejoras que se sugieren a la institución académica, con respecto al diccionario, no solo afectan a cuestiones léxico-semánticas, dado que también se inmiscuyen en la información que debe contener una obra de esas características. En este sentido, y en relación con la décima edición, se publicó una carta dirigida a la Academia con la firme proposición de que el diccionario contuviera un capítulo introductorio relativo a los orígenes del idioma:

Epístola dirigida á la Real Academia Española. Excma, señora: habiendo llegado á saber que V. E. trata de anunciar un certamen literario que ha de celebrarse en octubre del presente año, no hemos podido resistir á la tentación de advertirle, que hace notable falta un Resumen histórico de la lengua castellana, desde el principio de su formación hasta nuestros dias; escrito en tales términos, que pueda servir de introducción á su Diccionario, y si V. E. propusiera este asunto para el certamen, parécenos que tan notable falla quedaría desde luego remediada. Verdad es que en tan poco tiempo como queda para octubre, no puede escribirse una obra, que tan difícil es, y tanta erudición requiere. Pero esto se remedia con alargar el plazo del certamen, ya que ningún inconveniente hay en hacerlo. Esperamos que V. E. tome en cuenta esta indicación, aunque no sea mas que atendiendo á la buena voluntad, con que movidos de un sentimiento puramente patriótico se la hacemos. Dios guarde á V. E. muchos años, si ha de ser para honra y gloria de la lengua castellana. Madrid 24 de febrero de 1850. M. C DE S. (La Esperanza, 27/2/50: 4)

A pesar de ello, la más firme revisión, las sugerencias de corrección o las críticas ante las ausencias e inexactitudes se centran en el contenido léxico del DRAE, a veces con to-

20 Fue elegido académico honorario en 1827 y en 1833 pasaría a ser de número (www.rae.es/academicos/albertolista) 
nos despectivos o jocosos ${ }^{21}$. Queda soslayado durante este periodo el intento de crear una interacción comunicativa entre Academia y sociedad. De esa manera se demuestra con ejemplos como:

Grosa.-Enterado y medrado queda el pobre que quiera aprender algo en el Diccionario de la Real Academia de la Lengua, Grosa, dice el tal librazo, que es f. ant. que significa: gruesa en las catedrales. Se busca la palabra grueso-sa y dice el Diccionario: adj. Corpulento y abultado, grande, basto, ordinario, claro, fácil de entender, fuerte, duro y pesado, etc." Con lo cual nosotros nos creemos en el derecho de preguntar á quien contestarlo sepa y quiera: ¿Qué es gruesa en las catedrales? S. B. (El Averiguador 10/5/68: 3$)^{22}$

El periódico El Averiguador ${ }^{23}$, ya en las postrimerías del lapso acotado, comenzaba con una sección de preguntas y respuestas sobre diversos asuntos. Los suscriptores enviaban sus interrogantes, que, en el próximo número, eran contestados por los redactores. Un considerable número de dudas era el referido a cuestiones lingüísticas. Se pregunta por la ortografía, la etimología, el origen de determinados modismos o frases y hechas, junto a otros aspectos puramente léxicos, etc., siempre teniendo al diccionario de la Real Academia como referencia. No fue, sin embargo, el único medio que hacía notar ausencias o inexactitudes en las definiciones:

Por eso ahora antes de hablar de los asesinatos conviene presentar por delante la definición de la palabra asesinar tal como está en el diccionario de la academia española de la quinta edición, que es la única que tenemos. Dice pues que asesinar es matar alevosamente; y aunque ya se deja entender que ha de ser á otro individuo de su misma especie, con todo no hubiera sido del todo inútil espresarlo. Esta omisión que suponemos fundada en solidisimas razones, nace en gran parte de la costumbre en que estamos de no llamar robo ni asesinato al matar ó despojar á un animal de otra especie, sino que les damos el nombre de necesidad, instinto, ley de la naturaleza, razón, industria, y algunas veces también les llamamos arte. Ya se deja discurrir que esta nomenclatura es propia y peculiar de los gramáticos humanos, porque son los únicos que llenen la facultad de esplicarse; mas si supiésemos traducir el lenguage de los pavos, de los capones, de las codornices y de los peces, á buen seguro que los autores de los diccionarios de todas las academias se hubieran ido mas despacio para redactar este artículo. (El censor 27/10/21: 60)

21 El uso de la prensa para la publicación de críticas de carácter lingüístico se fue acrecentando conforme transcurría el siglo. A veces, estas apariciones eran anónimas o los verdaderos nombres de los autores de ocultaban bajo siglas o seudónimos. Otras, sin embargo, sí están firmadas. Como ejemplo de ello se pueden citar las críticas vertidas por Valbuena sobre el diccionario académico en los Los lunes del Imparcial, donde se incluyeron más de cien artículos con esta temática (Serrano 2006: 10).

22 Tras estas apreciaciones, se plantean cuestiones ortográficas del diccionario de gran interés como: “Armonía, arpa, celo.-¿Por qué la Real Academia Española escribe armonía, arpa, despojando á estas voces griegas de la h que tienen en el espíritu suave, y conservándola para las demás que se hallan en igual caso? Si se atuvo á la costumbre, deber suyo era corregir malas costumbres, cuando á tan poca costa pudo hacerlo, y no mirar autoridades que sólo en la costumbre se apoyaran. Es cierto que también escribe harmonía, aunque remitiendo al lector á armonía, é igualmente celo y zelo, que en su origen fué no más que zelo. Si en ortografía fuéramos á contar como diferentes modos de escribir todas las formas que la ignorancia ha solido dar á las palabras, además de la etimológica y legítima, vendríamos á parar en una verdadera algarabía. Armonía, arpa y celo, gracias á tales condescendencias, es como escribe la generalidad. Firmado por R."

23 Dirigido por Gregorio Cruzada Villaamil. 
Interesante se muestra la falta de concreción en determinados ámbitos sectoriales. En el léxico relativo a ellos se pronuncian interesantes opiniones acerca de las divergencia o ausencias que posee el diccionario académico a la hora de definirlo. Es el caso de determinados oficios u ocupaciones como el toreo:

Dice el Diccionario de la lengua castellana que toreador es "el que torea", y aunque la tal definición no nos ilumina gran cosa que digamos, nos satisface, sin embargo, y la admitimos, puesto que estamos en el secreto de que si los sabios académicos no dijeron lo bastante, pensaron decir algo mas, y fué: "Que por toreador se entiende el que torea por afición y sin recibir por su trabajo recompensa alguna." El torero es precisamente el reverso de la medalla. (Semanario Pintoresco Español 17/8/56: 5) ${ }^{24}$

La disculpa hacia la labor de los académicos no se produce en otros ámbitos. Todo lo contrario. El diccionario presenta inexactitudes a causa de los académicos, ocupados, según el periódico, en otros menesteres en vez del estudio de la lengua:

Seria útil, por cierto, tratar detenidamente, y con esto, reducir ó encerrar en pocos y expresos términos la gran cuestión en punto á las reglas filosóficas de la lengua, y demostrar á la luz de claros ejemplos, cual debiera de ser el método que se siguiese en la compilación de un nuevo diccionario (i) castellano, ordenado bajo el principio de que el conocimiento de las cosas es el que debe llevar al vocabularista á indagar y elegir las palabras. Pero ésta es empresa guardada para fuerzas mayores que las nuestras: empresa á que imperiosamente son llamados por obligación los señores individuos de la Academia Española: y mucho mas, cuando para acometerla, debiera mover á algunos de dichos señores, el solo recuerdo, de que hay tiempos en los que esta árida clase de estudios, salva á las almas de temple jeneroso, de la infamia de la adulación. Mejor parece, en efecto, un señor académico, cuando emplea su tiempo y vijilias en tareas propias de su dignidad literaria, que no viviendo en antesalas y secretarias, paramentada su persona con un negro frack de joyante paño.(El Artista 5/1/ 1835) ${ }^{25}$

Parte esta crítica del intento de acotar significativamente voces como oficio y profesión. Más adelante, otro colaborador del mismo periódico, ante la confusión que puede generarse en la aplicación de la palabra pintor, propone la diferenciación entre pintor y pintador:

PINTOR, el que profesa ó ejercita el arte de la pintura: dice el Diccionario de la lengua Castellana. Ahora bien, ¿puede aplicarse esta definición al que pinta puertas y ventanas? ¿merece el nombre de arte esta operación puramente mecánica? ¿puede llamarse artista al que revoca una casa, por ejemplo? [...] Digno objeto seria de las tareas academicas, corregir esta y otras imperfecciones de nuestro bellísimo idioma. Vaya otra indicación á los Sres. de la Academia de la lengua [...] PINTADOR. El que profesa ó ejerce la pintura, considerada como oficio mecánico. PINTOR. El que profesa ó ejerce la pintura, considerada como arte noble. Definiciones que podrían simplificarse mucho designando con diferentes voces las dos ideas que van anejas en ellas á la palabra pintura, y que hemos tenido que espresar por medio de un largo circunloquio. = E. DE O. ${ }^{26}($ El Artista 5/1/35)

24 En este caso hay una explícita disculpa hacia los académicos. En su desarrollo describe un amplio conjunto de voces de este oficio.

25 En nota al pie se propone la denominación de Vocabulario en vez de Diccionario.

26 Ese neologismo propuesto por el articulista entró en 1970, aunque no con el significado que sugería. 
Esos significados, diferentes a raíz de la especialidad en que se enmarquen, se dejan notar en terrenos como el de la fortificación

Quédame solo que encargar á mis discípulos, que teniendo en esta receta todos los elementos necesarios para conocer el arte de fortificación, no se metan en profundizar la ciencia, porque facilmente se embrollarian con las tenazas, tenazones, coronas, cortinas, lengua de sierpe, lunetas, caballeros, ó machos, y otras mil palabrotas que no tienen en la fortificacion la misma acepción que la que le dá el diccionario de la lengua castellana. (Revista nacional, 15/2/37: 3)

\section{la economía}

El Constitucional respondió que no era este el sentido que se podría dar á la voz transacción, ateniéndonos á la autoridad del diccionario de la lengua Castellana; mas de todos modos se alegró de saber, lo qué, por lo menos, una persona, entendía por dicha palabra, aunque está seguro que no es éste el que le daban otros muchos, sobre todo los primeros que la propalaron en un sitio publico. (El constitucional, 15/9/39:1)

o la gastronomía. En relación con esta última, se publicó un artículo interesante titulado "El Diccionario de la Lengua desde el punto de vista gastronómico" porque, según se explica, "El siglo XIX no solo se ha inmortalizado por los ferro-carriles, por la telegrafía eléctrica, por los gobiernos representativos con una ó dos cámaras, sino que alcanza también la gloría de haber impulsado el renacimiento de la ciencia gastronómica." El artículo, extenso y de gran interés, revela ausencias, anécdotas y determinados procederes en la redacción de artículos gastronómicos en el seno del Diccionario académico, en este caso el relativo a la décima edición. Esa falta de concienciación intenta explicarse porque "nuestros académicos, inspirándose sin duda en los consejos de cocineras vulgares, abriendo solo los oidos al dialecto de los jefes de los Ventorrillos de1 Manzanares, se obstinan en no dar cuartel á casi ninguno de los nuevos manjares, y en mantener en las columnas de su diccionario una nomenclatura gastronómica verdaderamente feudal". Si utilizamos el ejemplo de tortilla, leemos lo siguiente:

Tortilla es (Diccionario de la lengua, edición $10^{\mathrm{a}}$, pág.680, columna $1^{\mathrm{a}}$ ), una fritada de huevos batidos en aceite ó manteca, hecha en figura redonda á manera de torta, y en la cual se incluye de ordinario otro manjar. Prescindo de la forma redonda que despóticamente impone la Academia á la pobre tortilla, prescindo de lo vago de la indicación de que cabe incluir en ella otro manjar, lo cual puede hacer caer á inespertos cocineros en las mas estrañas aberraciones, y me ciño á lo de huevos batidos en aceite ó manteca. ¿Cabe concepción mas original? ¿Ha probado algún académico á hacer alguna tortilla por ese método? Definir así la tortilla es hacer imposible la tortilla, es mas, es inventar un nuevo plato sin saberlo. En efecto, si en vez de dejar tranquilo al aceite en la sarten, que harto tiene que hacer con que le frían, se obstina la Academia en batirle en frio con los huevos, resultará, salvo las claras, una especie de salsa mayonesa; y si después se empeña en freir esa mayonesa, resultará mayonesa frita. ${ }^{27}$

27 En la undécima edición (1869) se corrigió la definición, eliminando "en aceite o manteca" e indicando que la forma era comúnmente redonda, es decir, algún caso se debió hacer a la opinión aquí vertida. 
Para concluir con la convicción de que es necesario revisar y reformar el léxico de la gastronomía en el seno del diccionario:

Queda, pues, demostrado la urgencia de reformar la nomenclatura gastronómica consignada en el Diccionario, llamado en esta ocasión con evidente injusticia, de la Lengua. Para esto se ofrecen dos médios. O elevar á la Academia á un gran cocinero, lo cuál seria lo más derecho, ú obligar á los académicos á estudiar el tecnicismo gastronómico, bebiendo en buenas fuentes, comiendo en buenas mesas y consultando los clásicos de la nueva ciencia. (El imparcial 3/5/67) $)^{28}$

\section{EL DRAE EN EL CENTRO DE LA POLÉMICA}

Tras lo que estamos observando, el diccionario, y por extensión la Academia, se convierte en objeto de críticas, a la vez que despierta suspicacias. Esto provocará que se sitúe como eje de polémicas encarnizadas, a veces; constructivas, otras, aunque estas últimas sean las menos. Las citadas reacciones pueden estar motivadas bien por el contenido, bien por la relación del diccionario académico con otros diccionarios, próximos en el tiempo en cuanto a su publicación, generalmente. En la frontera temporal del periodo acotado, Jiménez Ríos (2013a y 2013b) ha estudiado las críticas efectuadas al diccionario por parte de autores como Antonio Valbuena, bajo los seudónimos de Miguel de Escalada o Venancio González, que desempeñó una intensa labor periodística.

\subsection{Por su contenido}

Este proceder, crítica al contenido (de forma general), ha ido vislumbrándose en el apartado anterior. En este primer caso, por tanto, se percibe que dichas críticas se generan a partir de las acepciones políticas de determinados vocablos, tal como sucede con ciudadano, haciendo clara referencia a la octava edición (1837):

Pocos aunque sean gente del pueblo ignorarán que el titulo de Ciudadano fué el nombre generico apelativo que se adoptó en la revolución francesa, y que duró hasta el famoso golpe do estado del 18 de Brumario. Y aunque en España se ha consignado también en nuestras Constituciones, no hay peligro de que se encuentre en el Diccionario de nuestra lengua, aun en el de la edición de 1837, la significacion política de la palabra ciudadano. El que por el Diccionario de la Lengua Castellana se proponga aprender la lengua castellana gran chasco se lleva. (El constitucional, 26/6/40: 1) $)^{29}$

\footnotetext{
28 Para criticar la actividad de los académicos en el diccionario, puede servirnos de ejemplo la mención a grodetur, que según el autor se incluyó porque la mujer de un académico, compró un nuevo tejido, gros, fabricado en Tours, y, debido a la pronunciación, lo interpretó como grodetur. El marido, una vez escuchada, procuró su inclusión en el diccionario. Parte, por tanto, de una anécdota para exhibir las deficiencias o arbitrariedades de algunas definiciones. Sin embargo, ya estaba presente en Terreros, y esta voz solo tuvo vitalidad en el diccionario académico entre 1817 y 1852, después de la décima edición desapareció.

29 Días después, el mismo articulista insiste con otra palabra, esta vez documento, y mantiene la misma opinión: "Pues diga, Vd. mi amo, ¿qué es documento? - Mira, si tratamos de saberlo acudiendo al Diccionario de la lengua, como propuso un diputado, no lo lograremos, porque ya me oíste el otro dia que quien por el Diccionario de la lengua castellana tratara de aprender la lengua castellana se llevaría gran chasco, pero documento según la admitida y común inteligencia, y según le define Mr. LEPEINTRE (que yo también tomo de los franceses lo qua de ellos me parece bien), es todo escrito que sirve de comprobación de un hecho, de un suceso, de una relación, de una historia,
} 
La reacción crítica no deja incólumes a los académicos redactores de la obra lexicográfica:

¡Qué poco iniciados debian estar los autores del diccionario de la academia española cuando definieron el verbo recíproco iniciarse diciendo que era recibir las primeras órdenes ú ordenes menores, como si despues de ser uno subdiácono, diácono y aun presbítero no pudiera iniciarse é iniciar á los demás en cuantos secretos y misterios humanos lleguen á su noticia! (El censor, 23/2/22: 31)

Precisamente, a la labor académica, en materia lexicográfica, se dirigen las críticas vertidas por Canalejas ${ }^{30}$ como introducción a la reseña que efectuó sobre el discurso de ingreso de Monlau en esa institución. Le asisten argumentos de inactividad y de no estar acorde con el tiempo en que vivía, lo que le incita a describir esa situación perniciosa para una labor y una obra de esas características:

Me apresuro a confesar que no es mayor la actividad de la Real Academia de la Lengua, y si en España las Reales Academias tienen altos deberes que cumplir, la real fundación de Felipe V, sino descuida el cumplimiento de dichos deberes, no tiene cuando menos conciencia de ellos. Pasan días y años y lustros y el diccionario no nos marca los adelantos conseguidos en esos años y en esos lustros; [...]Hablase de diccionario matriz, y la Academia calla; publícanse diccionarios Latino-español, grecohispano y se anuncia uno hebraico-hispano y la Academia no se estimula; cunde el desaliento entre los que rinden culto al habla castellana, y se augura y se teme y la Academia ni se desalienta ni teme; y por último, el crecimiento en la industria trae á nuestra lengua voces exóticas contra cuya formación protestan los cánones de la lengua castellana, y la Academia no escucha á los que á voz en grito piden un diccionario tecnológico. Pero quizá asisten á la Academia de la Lengua valederas razones para no aspirar á otra cosa que á la reimpresión de su diccionario y su gramática. (La América 24/8/59)

La presencia de neologismos era la deuda pendiente en ese momento, en lo concerniente al diccionario y dentro del intervalo que acaba con la décima edición. Pero la culpa no es exclusiva de la labor académica, también se hace extensiva a la sociedad porque no recurre a ella para comprobar y perpetuar el uso apropiado y los significados que deben disponer las voces españolas. Se convierte este tipo de escritos en una defensa velada, en parte, del diccionario. De esa manera se interpreta la renovación social influida por la cultura anglosajona, lo que implicaba cambios designativos del caudal léxico español y aumentaba el lamento ante la poca efectividad del $D R A E$ en esas circunstancias:

Si los ingleses llamaran tumulto á una procesión de rogativa, tumulto sería y no procesión, porque la interpretacion de las voces del Diccionario de la lengua castellana está hoy confiada á los ingleses, como lo prueba el hecho de acudir, no á nuestro Diccionario, sino á Inglaterra, para comprender la significación de las palabras libertad, revolución, progreso, fanatismo, soberanía, etc., etc (La Esperanza 13/12/54: 1)

do una memoria etc. y por consecuencia los títulos, piezas y objetos relativos á ella cuando están revestidos de la competente autenticidad, cuando llevan el sello de la verdad, de la certeza, o al menos de la probabilidad; esto se llama documento.- Asi me parecia á mí."(El Constitucional, 7/7/40: 1)

30 Tomó posesión como académico en 1869. 


\subsection{Por la relación con otros diccionarios}

Aunque en fechas tempranas el diccionario académico recibió críticas o comentarios, como ha estudiado Jiménez Ríos (1999), la publicación de obras de este tipo, al margen de las directrices académicas, supuso un hecho de gran repercusión y de enorme trascendencia en la historia de la lexicografía española. La consecuencia de encontrar en el mercado otros diccionarios, facilitó las comparaciones entre la labor académica y la efectuada fuera de sus confines e, incluso, propició el nacimiento de debates, polémicas y filiaciones hacia una u otra por parte de individuos que alcanzaron un alto grado de notabilidad en la época. Se puede decir que la prensa se convirtió en el mejor escaparate para mostrar esas opiniones y donde visibilizar las filias y las fobias hacia una obra que había alcanzado un considerable prestigio social.

Si el camino, durante el siglo XIX, se abre con los diccionarios de Arnao (1826) (Battaner 2008: 29) y Núñez de Taboada (1825) (Clavería Nadal 2007), no será hasta el año 1842, con la aparición, por entregas, del Panléxico de Peñalver cuando exista un verdadero punto de inflexión, a causa de las graves acusaciones vertidas, la enconada disputa entre los académicos y el autor y el impresor, así como la entrada en escena de los conceptos de autoría y plagio. Aspectos que han sido señalados por Clavería Nadal (2017: 113-121) o Azorín Fernández (2000: 241-247) quien destaca que la única originalidad del Panléxico radica en las citas de pensadores famosos. Estos cruces de acusaciones se reflejaron perfectamente en la prensa, que vivió con intensidad cada una de las declaraciones y opiniones que en sus páginas se vertían, alzándose como una de las noticias de mayor repercusión de ese año. $\mathrm{Al}$ margen de los artículos recogidos por el Conde de la Viñaza en la Gaceta de Madrid, que era el periódico "oficial”, se presentarán otros testimonios que mostrarán el interés informativo y la hartazón que provocaron ese cruce constante de acusaciones, a la vez que reflejará cómo se encontraba dividida parte de la sociedad, al menos la élite cultural, en cuanto a considerar ambos diccionarios. Llegados al último trimestre del año 1842, la editorial de $E l$ Corresponsal publicó un interesante artículo en el que pone de manifiesto las carencias del Panléxico, empezando por el título, y del diccionario académico:

El prólogo, introducción, ó lo que fuere, empieza con una amarga crítica sobre la obra de la Academia española. Difícilmente encontraremos otro libro que haya sido tratado con mas rigor [...] No es nueva esa manía de murmurar sin tino de la Academia, y no es la española la única que de semejantes ataques se ha visto hecha el juguete, aun antes de haberse hecho proverbial el epigrama del despechado Pirón. No es estraño: un asiento en la academia ha sido el sueño dorado de muchos literatos, gente por lo común envidiosa, vengativa y de maldito humor: no ha sido posible contentar á todos, y al que se vé chasqueado no le queda mas recurso que el de la zorra de la fábula. Asi ha ido cundiendo y haciéndose popular el resentimiento de unos pocos [...] No diremos si la Academia se ha aprovechado como debiera de los mismos ataques de sus contrarios, que alguna vez sin intención probablemente le han señalado razonables caminos; pero de todas mane ras ha habido sin duda grande exageración como en todas las cosas en que llegan á mezclarse las pasiones.

Para concluir, en una posdata, de la siguiente manera:

Teniamos escrito este artículo que por su estension reservábamos para nuestra tarea dominical, y entretanto la prensa se ha apoderado ya de la cuestión del PANLÉXICO. La polémica 
ha tomado un aspecto desagradable, y provocador que nos desalienta. Otros han juzgado mas severamente que nosotros al autor, quien en un comunicado de ayer al Diario de Madrid, se muestra indócil á toda razón y resistente á toda autoridad. Llegadas las cosas á tales estremos, ¿qué queda ya que hacer? Sentimos que en esta cuestión estén mezclados intereses mercantiles siempre respetables para nosotros, y mucho mas cuando estos se esponen generosamente con un deseo vivo del bien público y de la gloria nacional. Pero el patriotismo no siempre acierta en los medios: lo vemos todos los dias en otro orden de esfuerzos.

Sacada a relucir la cuestión mercantil, el argumento de la propiedad intelectual del diccionario fue uno de los ejes de la polémica, que destapó opiniones como la publicada en el Diario de avisos de Madrid, junto al tono desagradable que alcanzó en casi todos los periódicos nacionales de la época:

Por lo demás, no me persuado de que a nadie le haya ocurrido que la propiedad de la Academia consista en la facultad de publicar esclusivamente el Diccionario de la lengua [...] Creo, pues, que queda demostrado que por parte del editor D. Ignacio Boix, no hay ataque á la propiedad de nadie en la publicación del nuevo Diccionario, y que los señores redactores del Heraldo y el suscriptor de la Gazeta, hubieran hecho bien en limitarse a tratar del mérito literario de la obra, si lo juzgaban oportuno, pero sin hablar de una propiedad que solo ha existido en sus cabezas. Ahora solo añadiré, para concluir, que cualesquiera que fuesen los motivos que tuviera el suscriptor de la Gazeta para escribir contra el nuevo Diccionario, nunca podía tenerlos para haberlos espresado en los términos groseros en que lo hace en el último párrafo de su artículo, refiriéndose al autor y editor de la obra que censura, porque el comedimiento y la buena crianza nunca están reñidos con la razón. P. H. B.

Por ello, algunos de estos medios intentaban equilibrar la balanza con críticas a ambas obras. Es el caso de El espectador donde leemos:

El argumento mas fuerte, el único digno de la academia española era una nueva edición de su defectuoso diccionario, hecha con esmero, con filosofía, con Locke y Condillac en una mano, con Cervantes, León y Santa Teresa en la otra. Al señor Peñalver le quedaba la gloria de haber señalado el rumbo, de haber, cuando menos, despertado á aquella de su profundo letargo; y á la academia la de no haber ensordecido á la imperiosa voz de la civilización, del indispensable progreso de las ideas, cuyo eco es el Panlexico del señor Peñalver. Pero recurrir á tristes polémicas de periódicos, escasas de razón, salpicadas de observaciones necias y de gracias frias, apelar por último á una miserable sátira en que por todo argumento se dice que el autor del nuevo diccionario no puede hacer una cosa mediana, porque es comilón y mocero y tiene hambre; y no contentándose con sacar á relucir su vida y milagros, descender al sagrado recinto de una tumba para revolver los huesos de su padre, para echarle en cara que tradujo una novela.... el mismo que cada semana traduce un vaudeville; es ridículo, es repugnante, es indecoroso.

Hace referencia a la composición de Ventura de la Vega, titulada "El hambre: musa X" que contenía insultos velados al autor del Panléxico, lo que se convierte en una actitud reprobable para el periodista. Esa ausencia de argumentos sólidos sustenta la reseña publicada en El gratis:

Para criticar no basta llamarse escritor, ni tampoco serlo de insulsos periódicos y de mal forjados folletines: es preciso saber escribir; y solo debiera considerarse con derecho para 
atacar á un escritor el que se considerase capaz de presentar otra obra incomparablemente mejor que la que critica; y aun cuando asi fuese, siempre debemos respetar la buena intención del autor, su laboriosidad, y los generosos deseos que le animaron á ilustrar al público, empleando para ello su talento y sus luces. No basta decir esto no es bueno. Es preciso presentar otra cosa mejor, del contrario seria una injusticia el censurar una producción que siempre deberemos considerar útil y buena, mientras no se presente otra que la esceda en bondad y en utilidad.

Con el paso de los años, las opiniones se fueron suavizando y equilibrando e intentan proporcionar algún que otro consejo para evitar críticas en un futuro ${ }^{31}$ :

Empezando por la academia española, que semanalmente se reúne y que tiene pendientes trabajos de suma importancia en manos de comisiones, apenas deja oír su nombre respetable, sino cuando tiene que anunciar alguna nueva edición de su diccionario, al paso que si se diese cuenta al público de las discusiones, que no pueden dejar de ser luminosas, no solamente prestaría un gran servicio propagando los conocimientos de que es depositaria, no solamente haría partícipe á la nación de la gloria de sus trabajos, sino que dando á conocer los fundamentos de sus decisiones y la madura discusión de que son producto, hubiera probablemente evitado los desagradables ataques que ha tenido que sufrir, y en los cuales no han dejado de mezclarse la envidia y el despecho de los profanos. (El corresponsal 25/2/44: 3)

Hasta llegar a una situación, digamos, de normalidad lexicográfica:

Hablando de ese catálogo de medicamentos, dice el art. 38 (que cada diez años se revisará por el Consejo de Sanidad, y durante aquel período, claro es que no podía ser legal ni obligatoria la venta de los medicamentos que no estén oficialmente relacionados; viniendo á suceder con semejante prescripción, lo que con el Diccionario de la Academia Española, que por no contener todas las voces que el uso admite, se dan á conocer en otros diccionarios particulares que el público acepta sin violencia, porque encuentra en ellos lo que en el otro no ve). (Diario oficial de avisos de Madrid 21/ 6/ 60: 6)

Aunque la sospecha del plagio no desapareció totalmente:

Uno de los libreros de esta ciudad está publicando, y con muchísimos suscritores, un diccionario de bolsillo del idioma castellano, el cual es un compendio del de la academia española. Preguntas sobre esto: “¿Puede reimprimir el Diccionario la persona á quien se le antoje? ¿No debe la Academia para cumplir con el país, vigilar por que no se altere el idioma en publicaciones hechas por un librero cualquiera?" Veremos en lo que queda el asunto. (El Heraldo 3/12/45: 3$)^{32}$

\section{LAS EDICIONES DEL DRAE A LA PALESTRA}

Los comentarios hasta ahora expuestos nos facilitan el acercamiento a aspectos concretos, referidos al diccionario, y a su concepción social. No obstante, la prensa también se convir-

31 A partir de la publicación del Diccionario de Domínguez, esta situación parece normalizarse y en la prensa se sitúan definiciones conjuntas del diccionario académico y el de este autor, sin opiniones y sin acritud.

32 Bien puede tratarse del Diccionario Portátil y Económico de la Lengua Castellana, editado por la imprenta de Juan Roca y Suñol, Barcelona, en 1842 (por entregas), cuya autoría aparece bajo las siglas B.C.H.I.P.S. 
tió en el medio donde exponían las opiniones sobre determinadas ediciones del diccionario académico. Sabemos por Jiménez Ríos (2013a) que la primera reseña publicada fue la correspondiente a la décimo tercera edición (1899), es decir, que son ediciones posteriores a las que estamos dedicando la trayectoria periodística de este trabajo. La prensa, por su parte, sí ofreció opiniones sobre ediciones concretas que no se corresponderían estas con el significado exacto de "reseña". Por ello, si se hace referencia en alguna ocasión a este término, entiéndase en sentido muy amplio y como opinión crítica, sobre todo. En general a penas se encuentran con anterioridad a 1837, la octava edición, pues solo los diccionarios de Arnao y Núñez de Taboada disputaban el monopolio lexicográfico en el siglo XIX. Sobre la séptima edición, 1832, se introdujo, en una nota al pie, un extenso comentario, definido por su autor como un artículo más del periódico. A pesar de no estar mencionada la fecha, la constatación de las páginas que se aluden no deja lugar a dudas acerca de texto manejado por el periodista.

Por nuestra parte desearíamos que, en este caso, y otros semejantes, procurase el Diccionario ser un poco mas ecsacto: lo que, sin mucho trabajo de los señores Académicos, acarrearía mucho provecho á los que no teniendo un conocimiento tan profundo de nuestra lengua, como dichos señores, necesitamos que el Diccionario, en partes nos la enseñe, pero bien y ecsactamente. [...] Limpien, fijen, y acrisolen, como deben los señores Académicos, el sentido y significación de los vocablos en el Diccionario; [...] Un Académico, y de los mejores, ha dicho muy bien, que el comento nuevo al Quijote, pretende probar que puede escribirse un admirable libro, sin necesidad de gramática. ¡Estraño comento y estraña tarea para un académico de la lengua! Mucho mejor parece el ocuparse en rectificar el Diccionario: que miles de definiciones suyas son malísimas ${ }^{33}$. Esto lo podríamos probar con muchísimos ejemplos.- He aquí alguno: dice en la pag. 690 — Sinceridad, f. Pureza, sencillez [...] (El Artista, 1/4/35)

El Diario del Gobierno de México (27/3/39) se hizo eco de una reseña aparecida en la Gaceta de Madrid sobre la $8^{a}$ edición, 1837. En una extensa columna, se reproduce literalmente el prólogo de la edición del diccionario para, a continuación, proceder a comentar los cambios que señalan en él. De forma previa, se incluyen palabras afines a la labor académica con respecto al diccionario, expresadas de la forma siguiente:

El escelente prólogo que antecede á esta edición, contiene muchas reflecsiones importantes, algunas de las cuales responden a las objeciones que ciertos críticos mal informados han solido hacer contra el Diccionario de la lengua. Decimos mal informados, porque es muy común creer que ecsiste en la academia alguna autoridad suprema para dictar leyes al lenguaje y á la escritura, y dar ó quitar la ciudadanía á las voces y á las locuciones. Así muchos, por ejemplo, se quejan de que algunas voces falten del Diccionario, ó de que no se hayan hecho en la ortografia las correcciones que ellos desearan. Pero es necesario que estos críticos, y con ellos el público ilustrado, se convenzan de que ni ecsisten ni pueden ecsistir semejantes facultades en la academia. Tiene que obedecer, como los que hablan y escriben el idioma, á una autoridad sin apelación, que es la del uso, supremo legislador en materia de lenguaje. Sus decisiones son diversas, y á veces contrarías, pero añade, quita, modifica á su voluntad, y sus variaciones tienen siempre fuerza de ley. L a academia española, por la esencia de su instituto, ni es ni puede ser otra cosa sino intérprete de esta voluntad soberana. (Diario del Gobierno de la República de México,27/3/39: 4)

33 No sabemos si se referiría a Diego de Clemencín, autor de una de las ediciones de El Quijote. 
En consonancia con estos argumentos, se introduce un largo discurso que justifica la posición de la Academia con respecto a los neologismos, sobre todo los procedentes de las ciencias y las técnicas, así como de las apreciaciones sobre la ortografía. En ambos casos, el autor muestra su acuerdo con las decisiones adoptadas en el diccionario.

La edición que copa el interés periodístico fue la novena edición. Probablemente contribuyó a ello el hecho de que la precediera la publicación del Panléxico, por lo que contaba, antes de su publicación, con una amenaza:

estriban en que la Academia española tiene hecho ya el acopio de papel para la novena edición de su Diccionario, y si es por el estilo de las últimas, nos probará mas y mas que solo tiene de Academia el nombre, pues se ha propuesto no dejar piedra sobre piedra en la obra de los Clemencines y Jovellanos, de los Quintanas y los Listas. No crean sin embargo los enemigos del autor del Panléxico [los académicos] que sus huecas frases correrán impresas sin correctivo, Al Heraldo, y la Gaceta diremos á su tiempo cuatro verdades, y no se las negaremos al ministro de la Gobernación, porque manda insertar en el periódico oficial libelos infamatorios, en lugar de barrer de los caminos públicos los ladrones que los infestan. (Revista de Teatros 22/1/42: 6)

Fue esta edición anunciada con gran pompa y boato en casi todos los periódicos del momento, sobre todo, se describió la entrega de los dos primeros ejemplares a la Reina y a su hermana por parte del director y el secretario perpetuo de la institución:

El Excmo. Sr. D. Francisco Martínez de la Rosa, director de la Real Academia Española, y el Ilmo. Sr. don Juan Nicasio Gallego, secretario perpetuo de la misma, tuvieron ayer la honra de felicitar á la Reina en nombre de dicho cuerpo por la fausta declaración de la mayoría de edad de S. M. hecha por Las Cortes. Al mismo tiempo ofrecieron reverentemente á sus reales pies para uso de S. M. y, de su augusta Hermana la Sra. Infanta doña María Luisa, los dos primeros ejemplares de la nueva edición del diccionario de la lengua castellana. S. M. y A. manifestaron recibirlo con mucho aprecio, dispensando á los comisionados de la Academia el honor de besar sus Reales manos. (El corresponsal, 16/11,43 p.3)

La opinión repetida se articula a partir de argumentos negativos sobre la novena edición, utilizados, a su vez, para verter las críticas más despiadadas contra los académicos:

Respecto de Diccionario, no diremos nada, porque el de la novena edición, última que ha dado á luz hace siete años, es en nuestro concepto el mas defectuoso de cuantos ha publicado. Y no crean nuestros lectores que es por falta de académicos, pues sepan que hay sobrado número, y apenas vaca una plaza, al momento sale provista. De supernumerarios y honorarios no se hable, porque estos son infinitos: de manera que en este punto nos hallamos como con los empleados, que estamos peor servidos cuantos mas tenemos. (La Esperanza, 12/3/50: 1)

El deseo manifestado en la prensa se traduce en la esperanza de que los defectos detectados sean mejorados en la próxima edición, la décima:

Nos han asegurado que la Academia Española está haciendo nueva edición del diccionario de la Lengua Castellana. Si es asi, la aconsejamos que procure sea mejor que la última, ó por lo menos que se corrijan las faltas graves de que ésta adolece. No es ahora la primera 
vez que tomamos la pluma para hablar de asuntos de esta especie: en otras ocasiones hemos censurado el atraso en que dicha corporación tiene los ramos de su incumbencia. (La Esperanza 21/2/51: 1)

Para que se produzca la mejora, el artículo se refiere a definiciones defectuosas, la supresión de arcaísmos (descriptor, encomiar), vacilaciones como lesna y lezna, respecto a y respecto de, las faltas de ortografía como a cuévano con b, a harina, sin h, para concluir que "En fin haremos alto aquí y diremos que si la Academia ha de publicar un diccionario mejor que el actual, es menester que sus individuos trabajen mas que hasta ahora". ${ }^{34}$

Respecto a la décima edición, no hemos encontrado comentarios reseñados de este tipo, aunque fue anunciada en casi todos los periódicos del momento. La publicidad, en este caso, ofrecía cierto engaño porque, en ocasiones, el diccionario de 1852 anunciado podría ser la segunda edición del elaborado por José Caballero. No obstante, a partir de esta fecha, sí se anuncian con profusión los trabajos para la undécima. Lo que no desaparecerá con el paso de los años será la competencia entre los diversos productos que saldrán al mercado en fechas próximas, siempre con el afán de ser mejor que todos los anteriores publicados.

\section{A MANERA DE CONCLUSIÓN}

Para finalizar, podríamos extraer varias conclusiones después de todo lo expuesto, dado que el diccionario académico se convierte, durante la primera mitad del siglo XIX, en una autoridad que se difunde entre capas sociales cada vez más amplias. En este sentido, el periodismo es un testimonio de vital importancia para comprender esa evolución y hasta qué punto esa parte de la sociedad estaba comprometida e implicada en mejorar, a través de sus críticas o elogios, el repertorio lexicográfico más importante de nuestra lengua, pues el diccionario se había alzado como una realidad que no dejaba indiferente a sus usuarios. Por ello, la prensa es el escenario propicio en el que escenificar y traer a colación lo que esos usuarios esperan de él y no encuentran, o, sencillamente, sí lo hacen y lo elogian. Es este también el momento en el que comienza la interacción sociedad-Academia, pues muchos de los ejemplos usados en este trabajo modificaron su definición en el diccionario, a raíz de los comentarios aparecidos en la prensa.

El diccionario es, por tanto, una realidad poliédrica en las páginas de la prensa del momento porque es objeto de atención desde las más diversas perspectivas. Aunque, a veces, resulte imposible asegurar la edición manejada, los articulistas, más o menos cercanos al quehacer lexicográfico, vierten sus opiniones o fundamentan el contenido de sus escritos mediante el uso del diccionario académico durante el periodo en que se publicaron la quinta y la décima edición.

La entrada en escena de la lexicografía no académica, sobre todo con el Panléxico, introdujo críticas y aspectos más severos que, con el paso del tiempo, fueron dulcificándose o encontrando unos razonamientos más comedidos. Con toda seguridad, por este motivo, la edición más vilipendiada sea la novena, en justa correspondencia con las desagradables comparaciones que se hicieron con la obra de Peñalver. Así mismo, no se puede obviar que la crítica al diccionario está fundamentada en una crítica a sus autores, los académicos, que despertaron envidias entre escritores contemporáneos.

34 Este artículo fue publicado de manera resumida en El Observador 22/5/51 p.3. 
Podríamos decir que esta edición, la novena, fue un punto de inflexión en cuanto a la implicación ciudadana y en convertir el diccionario en noticia. Pero también hubo otro punto de inflexión en la octava a través de la reseña o nota aparecida sobre su prólogo, porque surge el argumento de que la Academia no censura, no impone, la Academia, a través del diccionario, recoge el uso de nuestras palabras. Es decir, la prensa es un testimonio de vital importancia para conocer la evolución del diccionario, a la vez que nos ofrece nuevas perspectivas de trabajo e investigación en parcelas poco transitadas hasta ahora.

\section{REFERENCIAS BIBLIOGRÁFICAS}

AA.VV. (2012): Las Cortes de Cádiz y la Constitución de 1812. Madrid: Alianza Editorial.

Álvarez de Miranda, P. (1992): Palabras e ideas: el léxico de la Ilustración temprana en España (1680-1760). Madrid: Anejos del Boletín de la Real Academia Española, LI.

Álvarez de Miranda de la Gándara, P. (2011): En doscientas sesenta y tres ocasiones como esta. Discurso leído el 5 de junio de 2011 en su recepción pública. Madrid: Real Academia Española.

Azorín Fernández, D. (2000): Los diccionarios del español en su perspectiva histórica. Alicante: Universidad de Alicante.

Barrera, C. (ed.) (2000): El periodismo español en su historia. Barcelona: Ariel Practicum.

Battaner Arias, M ${ }^{a}$ P. (2008): "La Real Academia Española en las Cortes de Cádiz (1810-1814)". Boletín de la Real Academia Española. 88, cuaderno 297, pp. 5-32.

Clavería Nadal, G. (2007): "Historia del léxico en los diccionarios: la deuda del Diccionario de la Lengua Castellana de la Real Academia con los diccionarios de M. Núñez de Taboada". Revista de Historia de la Lengua Española, 2, pp. 3-27.

Clavería Nadal, G. (2017): De vacunar a dictaminar: la lexicografía académica decimonónica y el neologismo. Madrid: Iberoamericana.

Garriga Escribano, C. (2018): "Las voces de la Química". En Clavería, G. y Freixas, M. (coords.). El diccionario de la Academia en el siglo XIX: la $5^{a}$ edición (1817) al microscopio. Madrid: Arco Libros, pp. 313-337.

Jiménez Ríos, E. (1999): "Algunas críticas tempranas al diccionario de la academia". Thesaurus, Boletín del Instituto Caro y Cuervo. 54, 3, pp. 1071-1101.

Jiménez Ríos, E. (2013a): Divulgación y especialización lexicográfica: el DRAE a la luz de sus reseñas. Vigo: Academia del Hispanismo.

Jiménez Ríos, E. (2013b): La crítica lexicográfica y el diccionario de la Real Academia Española: obras y autores contra el diccionario. Anejos de la Revista de Lexicografia, 21. A Coruña: Universidade.

Morales Umpiérrez, J. C. (2013): "La conjuración de las palabras y el viaje del Parnaso: Un cuento y una novela actuales". En Actas del octavo congreso internacional de estudios galdosianos. Las Palmas de Gran Canaria: Cabildo Insular de Gran Canaria, pp. 139-147.

Moreno Moreno, Ma Á. (2009): "La recepción del vocabulario de los primeros liberales", Las ideas y realidades lingüísticas en los siglos XVIII y XIX. Cádiz: Universidad de Cádiz, pp. 467-481.

Peñate Rivero, J. (1989): "Benito Pérez Galdós y la 'conjuración de las palabras"”. Boletín de la Institución Libre de Enseñanza. 9, pp. 50-71.

Real Academia Española (en línea): Nuevo Tesoro Lexicográfico de la Lengua Española. www.rae. es $(17 / 02 / 2018)$.

Sellés, E. (1895): Discursos leidos ante la Real Academia Española en la recepción pública de don Eugenio Sellés el día 2 de junio de 1895. Del periodismo en España. Madrid: Imprenta de la Revista de Navegación y Comercio.

Serrano Serrano, J. (2006): "Polémicas de Antonio Valbuena con sus contemporáneos sobre la corrección gramatical y los defectos del Diccionario de la Academia", Estudios humanísticos. Filología, 28 , pp. 189-223. 
Shoemaker, W. (1972): Los artículos de Galdós en "La Nación”, recogidos, ordenados y dados nuevamente a la luz con un estudio preliminar. Madrid: Ínsula.

\section{Periódicos consultados}

Boletín de medicina, cirugía y farmacia

Crónica científico y literaria

Diario constitucional de Palma

Diario del Gobierno de la República de México

Diario del Gobierno de los Estados-Unidos Mexicanos

Diario oficial de avisos de Madrid

Eco del comercio

El Artista

El Averiguador

El censor

El clamor público

El constitucional

El correo

El corresponsal

El español

El espectador

El gratis

El Heraldo

El imparcial

El moro Muza

El panorama

El revisor semanal

Gazeta de Madrid

La América

La Educanda

La Esperanza

La Iberia

La Ilustración

La Nación

Museo de los niños

Revista de Teatros

Revista nacional

Semanario Pintoresco Español

Semanario político 